\title{
Massimo del Pizzo, Se l'altro non esiste. Fantastico e immaginazione scientifica nel Novecento
}

\section{Emanuele Kanceff}

\section{(2) OpenEdition}

\section{Journals}

\section{Edizione digitale}

URL: http://journals.openedition.org/studifrancesi/36571

DOI: 10.4000/studifrancesi.36571

ISSN: 2421-5856

Editore

Rosenberg \& Sellier

\section{Edizione cartacea}

Data di pubblicazione: 1 juillet 2005

Paginazione: 193-194

ISSN: 0039-2944

\section{Notizia bibliografica digitale}

Emanuele Kanceff, «Massimo del Pizzo, Se l'altro non esiste. Fantastico e immaginazione scientifica nel Novecento», Studi Francesi [Online], 145 (XLIX | I) | 2005, online dal 30 novembre 2015, consultato il 19 avril 2021. URL: http://journals.openedition.org/studifrancesi/36571 ; DOI: https://doi.org/10.4000/ studifrancesi.36571

Questo documento è stato generato automaticamente il 19 avril 2021.

\section{(c) $(1)$}

Studi Francesi è distribuita con Licenza Creative Commons Attribuzione - Non commerciale - Non opere derivate 4.0 Internazionale. 


\title{
Massimo del Pizzo, Se l'altro non esiste. Fantastico e immaginazione scientifica nel Novecento
}

\author{
Emanuele Kanceff
}

\section{NOTIZIA}

MASSIMO DEL PIZZO, Se l'altro non esiste. Fantastico e immaginazione scientifica nel Novecento, Bari, Università di Bari, Edizioni B. A. Graphis, 2004 (Collana "Ecarttrace" diretta da Bruno Pompili), pp. 158.

Si tratta di una collezione di saggi già pubblicati in precedenza, ma qui rielaborati al fine di rendere unitario l'effetto di questo originale libro. Il progetto «non è dunque il recupero di pagine sparse, bensì la miglior definizione di studi prima solo abbozzati o anche incompiuti, maturati poi attraverso nuove letture e nuove curiosità» e lo scopo è quello di cogliere una fiction nutrita di cultura letteraria e quindi migliore di quella che i media ci ammanniscono. Ma questo senza conceder nulla alle pretese di razionalità che, in nome della spirito scientifico, alimentano la diffidenza verso una "incolpevole fantascienza letteraria". Il complesso di questi scritti, di cui almeno due inediti, è rivolto al problema letterario generale della fantascienza: ma l'ultima parte del libro si occupa specificamente dell'area francofona, con Jules Verne e Rosny Aiiné. 